JURNAL NATAPRAJA

Kajian Ilmu Administrasi Negara

Vol. 6, No. 1, 2018 https://journal.uny.ac.id/index.php/natapraja

pp. 69-84

\title{
INOVASI PELAYANAN AKTA KELAHIRAN MELALUI EGOVERNMENT DI DINAS KEPENDUDUKAN DAN PENCATATAN SIPIL KOTA YOGYAKARTA
}

\author{
Eko Kurnia Putri ${ }^{1}$ dan Argo Pambudi ${ }^{2}$ \\ Jurusan Ilmu Administrasi Negara, Fakultas Ilmu Sosial, Universitas Negeri Yogyakarta \\ 1ekokurniaputri@gmail.com \\ ${ }^{2}$ argo_pambudi@uny.ac.id
}

\begin{abstract}
This research aimed to deeply understand the innovation and the supporting and inhibiting factors innovation of birth certificate service by E-Government. The research design used in this research were descriptive with qualitative approach. The research design was considered able to explain this research in depth. The results showed that the Innovation of Birth Certificate Services by E-Government in Yogyakarta's Department of Population and Civil Registration has not been optimal. It could be seen by the five indicators of innovation of public service according to Rogers advantages, compatibility, complexity, triability, and observability. From those five dimensions, it could be showed that the inovation has not been optimal by these case: 1) the number of users in online birth certificate making service were low, 2) the service innovation offered by the government were numerous, 3) there were no special officers who take care of the online birth certificate making service, 4) the online birth certificate making service was still conducted partially, 5) The citizen's ignorance about the online birth certificate making service. There were also various supporting and inhibiting factors in the innovation of birth certificate making service by e-Government that conducted by the Yogyakarta's Department of Population and Civil Registration.
\end{abstract}

Keywords: Innovation, Birth Certificate Services, e-Government

\begin{abstract}
Abstrak
Penelitian ini bertujuan untuk memahami inovasi dan mengetahui faktor pendukung dan penghambat inovasi pelayanan akta kelahiran melalui e-Government. Desain penelitian yang digunakan adalah deskriptif dengan pendekatan kualitatif. Desain penelitian ini dianggap mampu menjelaskan penelitian ini secara mendalam. Hasil penelitian ini menunjukkan bahwa Inovasi Pelayanan Akta Kelahiran melalui E-Government di Dinas Kependudukan dan Pencatatan Sipil Kota Yogyakarta belum optimal. Hal tersebut dapat dilihat dari lima indikator inovasi pelayanan publik menurut Rogers yaitu kebaruan, kesesuaian inovasi, kerumitan, kemungkinan dicoba, dan kemudahan diamati. Dari kelima indikator tersebut, hal yang menunjukkan belum optimalnya inovasi pelayanan publik yaitu: 1) jumlah pengguna akta kelahiran online rendah, 2) inovasi pelayanan yang ditawarkan pemerintah terlalu banyak, 3) belum ada petugas khusus yang melayani akta kelahiran online, 4) pelaksanaan pelayanan akta kelahiran online yang masih parsial, 5) ketidaktahuan masyarakat terkait inovasi pelayanan akta kelahiran online. Dalam inovasi pelayanan akta kelahiran melalui e-Government yang dilakukan Dinas Kependudukan dan Pencatatan Sipil Kota Yogyakarta juga terdapat berbagai faktor pendukung dan penghambat inovasi pelayanan akta kelahiran.
\end{abstract}

Kata kunci: Kepatuhan, Larangan Merokok dan Studi Komparatif.

Diterima 4 April 2018; Diterima dengan revisi 21 April 2018; Dipublikasikan 1 Mei 2018

2406-9515 (p) / 2528-441X (e)

(C) 2018 Eko Kurnia Putri dan Argo Pambudi. Dipublikasikan oleh JIAN FIS UNY 


\section{PENDAHULUAN}

Fenomena yang terjadi dalam pelayanan publik merupakan hal yang selalu menarik untuk dibahas. Saat ini kebutuhan pelayanan publik merupakan salah satu hal yang pokok dan menjadi perhatian utama pemerintah baik oleh pemerintah pusat maupun pemerintah daerah seiring dengan dikeluarkannya Undang-undang Nomor 25 Tahun 2009 yang mengatur mengenai Pelayanan Publik. Dengan adanya Undang-undang tersebut, kompleksitas kebutuhan masyarakat terkait pelayanan juga ikut meningkat dan kesiapan pemerintah juga diperlukan dalam menyelenggarakan pelayanan.

Dalam rangka upaya peningkatan kualitas pelayanan publik, pemerintah memiliki kewajiban untuk melakukan perubahan ke arah yang lebih baik. Peningkatan performa pelayanan dapat dilakukan dengan melakukan sebuah terobosan yaitu melalui inovasi pelayanan publik. Kebutuhan terhadap inovasi pelayanan publik bagi peningkatan pelayanan sesuai dengan pendapat yang disampaikan Khairul Muluk (2008:43) yaitu:

"Inovasi sektor publik dibutuhkan untuk memberikan layanan publik yang lebih mencerminkan ketersediaan bagi pilihan-pilihan publik dan menciptakan keanekaragaman metode pelayanan."

Berdasarkan pendapat di atas, Inovasi dapat dimanfaatkan untuk meningkatkan kualitas pelayanan dan dampaknya bagi masyarakat terutama untuk mengatasi kebijakan sebelumnya yang kurang menampakkan hasil yang memuaskan. Inovasi pelayanan publik juga memberikan tawaran dan alternatif yang penting dalam peningkatan kualitas pemerintah terhadap kebutuhan masyarakat.

Pemanfaatan teknologi informasi dan komunikasi merupakan kenyataan yang semakin berkembang dalam situasi pelayanan publik saat ini. Hadirnya konsep cyber city juga mendorong kotakota di daerah untuk mengadopsi konsep tersebut. Pemikiran ini lah yang sesuai dengan pemerintah pusat yang menetapkan program pengembangan teknologi informasi dan komunikasi yang lebih dikenal dengan istilah $e$ Government (Electronic Government). EGovernment telah menjadi bagian yang penting dalam proses pembangunan nasional terutama hal pelayanan.

Salah satu bentuk pelayanan publik yang diselenggarakan oleh pemerintah adalah pada bidang pelayanan administrasi kependudukan yaitu akta 
kelahiran yang merupakan data yang sangat penting dimiliki oleh seseorang. Mencatatkan peristiwa atau kejadian penting individu pada register akta di Dinas Kependudukan dan Pencatatan Sipil berarti menyimpan dokumen status kependudukan dengan jaminan kepastian hukum yang dimiliki seseorang dalam status kewarganegaraannya. Permasalahan yang timbul dalam hal ini adalah tidak sedikit masyarakat yang belum mengetahui arti penting kepemilikan akta kelahiran.

Hasil Survei Sosial Ekonomi Nasional (Susenas) oleh Kementrian Perencanaan Pembangunan Nasional/Badan Perencanaan terkait alasan masyarakat tidak memiliki akta secara nasional dapat dilihat bahwa alasan masyarakat yang tidak memiliki akta berumur 0 sampai 17 tahun didominasi oleh faktor tidak memiliki biaya untuk mengurus akta kelahiran sebanyak 33,87\%. Sedangkan alasan masyarakat yang paling rendah adalah masih ada masyarakat yang tidak tahu bahwa akta kelahiran harus dicatatkan. Alasan masyarakat tidak memiliki akta paling besar kedua adalah terkait belum terbitnya akta kelahiran sebanyak $19,79 \%$, sehingga hal ini menjadikan salah satu alasan masyarakat enggan untuk melanjutkan mengurus akta

kelahiran. Beberapa hal di atas tentu saja menjadi perhatian pemerintah sebagai penyelenggara pelayanan terkait administrasi data kependudukan dan pentingnya kepemilikan akta kelahiran bagi masyarakat.

Terkait arti penting pelayanan publik terutama dalam hal administrasi kependudukan terhadap akta kelahiran, Dinas Kependudukan dan Pencatatan Sipil Kota Yogyakarta telah melakukan sebuah inovasi. Inovasi pelayanan akta kelahiran online dilakukan karena permintaan jumlah akta kelahiran di Kota Yogyakarta termasuk tinggi. Hal ini sesuai dengan pernyataan yang telah dijelaskan oleh Kepala Dinas Kependudukan dan Pencatatan Sipil (Disdukcapil) Kota Yogyakarta Sisruwadi dalam salah satu buletin harian online:

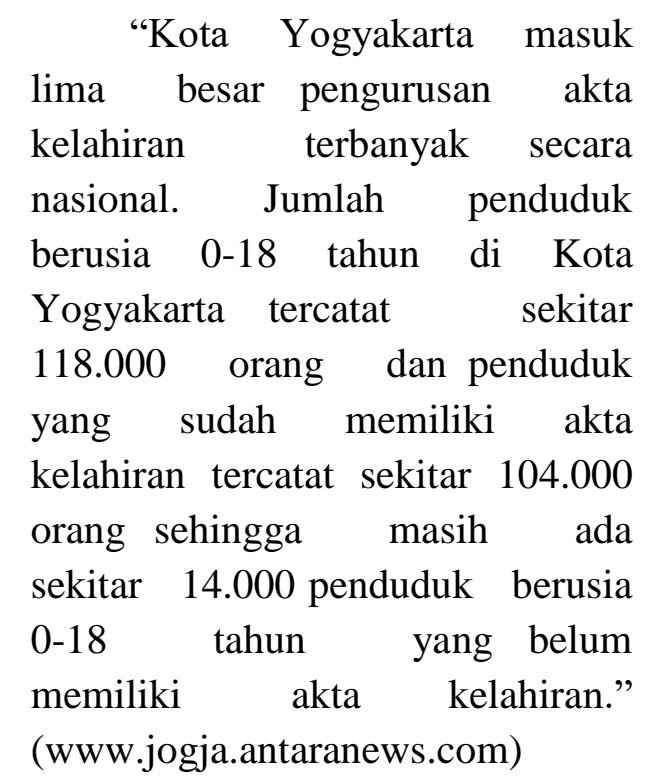


Sebagian penduduk di Kota Yogyakarta masih ada yang belum memiliki akta kelahiran. Padahal dalam setiap kelahiran, seseorang perlu memiliki bukti tertulis dan otentik karena dapat membuktikan identitas seseorang dengan pasti dan mempunyai kekuatan pembuktian di mata hukum.

Di Yogyakarta khususnya, Undangundang yang mengatur tentang kependudukan adalah Peraturan Daerah Kota Yogyakarta Nomor 8 tahun 2012 tentang Penyelenggaraan Administrasi Kependudukan yang diperkuat oleh Peraturan Menteri Dalam Negeri No.9 tahun 2016 tentang Percepatan Peningkatan Cakupan Akta Kelahiran. Peraturan tersebut menjadi dasar acuan Pemerintah Kota Yogyakarta untuk menyelenggarakan pelayanan akta kelahiran. Penyelenggaraan pelayanan ini juga tidak terlepas dari tugas pemerintah untuk melakukan pelayanan yang cepat dalam mendukung kebijakan terkait percepatan peningkatan cakupan akta kelahiran.

Penelitian ini dimaksudkan untuk mengetahui bentuk inovasi pelayanan akta kelahiran melalui e-Government di Dinas Kependudukan dan Pencatatan Sipil Kota Yogyakarta serta mengetahui faktor pendorong dan faktor penghambat inovasi pelayanan akta kelahiran melalui
e-Government di Dinas Kependudukan dan Pencatatan Sipil Kota Yogyakarta.

Menurut Khairul Muluk (2008:45) Inovasi dalam metode pelayanan publik adalah cara baru dalam memberikan pelayanan. Dalam melakukan proses inovasi, inovasi pelayanan publik memiliki indikator untuk mengetahui keoptimalan sebuah inovasi. Berikut ini indikator inovasi pelayanan publik menurut Rogers (dalam Yogi Suwarno, 2008:17-18):

1. Relative Advantage atau

2. Keuntungan Relatif.

3. Compatibility atau Kesesuaian.

4. Complexity atau Kerumitan.

5. Triability atau Kemungkinan dicoba.

6. Observability atau Kemudahan diamati.

Peneliti menggunakan teori utama inovasi pelayanan publik menurut Rogers (dalam Yogi Suwarno 2008:16-18) dengan alasan bahwa dari adanya indikator inovasi pelayanan menurut Roger yang disebut dengan atribut inovasi, dapat menjawab optimal atau tidaknya sebuah inovasi secara lebih mendalam.

Penelitian ini relevan dengan penelitian yang dilakukan oleh Nur Ayyul Hisbani, dkk Jurusan Ilmu Administrasi Negara Fisipol Unismuh 
(2015) dengan judul "Penerapan Inovasi Pelayanan Publik di Dinas Kependudukan dan Catatan Sipil Kabupaten Enrekang”. Adapun kesamaannya adalah cara menganalisis inovasi dengan menggunakan teori Rogers yang meliputi relatif advantage (keuntungan relatif), compability (kesesuaian), complexity (kerumitan), triability (kemungkinan dicoba), dan observability (kemudahan diamati).

Penelitian ini penting dilakukan karena diharapkan hasil dari penelitian ini dapat memberikan rekomendasi kepada Pemerintah Kota Yogyakarta dalam mengevaluasi inovasi pelayanan akta kelahiran secara online.

\section{METODE}

Desain penelitian yang digunakan dalam penelitian ini adalah penelitian metode kualitatif. Metode kualitatif ini merupakan suatu metode untuk mengesplorasi dan memahami makna yang muncul dari suatu fenomena ataupun yang berasal dari suatu permasalahan sosial (Creswell, 2012). Penelitian ini dilaksanakan pada bulan Januari hingga bulan April 2018. Sementara itu, peneliti mengambil tempat penelitian di Kantor Dinas Kependudukan dan Pencatatan Sipil
Kota Yogyakarta dengan alamat Kompleks Balaikota Yogyakarta Jalan Kenari 56 Yogyakarta.

Teknik analisis data yang digunakan dalam penelitian ini adalah teknik analisis data interaktif model Miles and Huberman. Menurut Miles dan Huberman dalam buku Sugiyono (2011), aktivitas analisis data kualitatif dilakukan secara interaktif dan berlangsung secara terus menerus sampai tuntas, sehingga datanya sudah jenuh. Aktivitas dalam analisis data, yaitu Data Reduction (Reduksi data), Data Display (Penyajian data), dan Verification (kesimpulan).

\section{HASIL DAN PEMBAHASAN}

Inovasi pelayanan publik sangat dibutuhkan untuk meningkatkan pelayanan pemerintah bagi perkembangan kebutuhan masyarakat yang semakin kompleks. Sehingga dalam pelaksanaannya, pemanfaatan teknologi informasi dan komunikasi merupakan kenyataan yang semakin berkembang dalam situasi pelayanan publik saat ini.

Hal di atas sesuai dengan yang diamanatkan pada Peraturan Daerah Kota Yogyakarta Nomor 8 tahun 2012 tentang Penyelenggaraan

Administrasi Kependudukan yang diperkuat oleh Peraturan Menteri Dalam Negeri No.9 tahun 2016 tentang Percepatan 
Peningkatan Cakupan Akta Kelahiran, dimana telah menjadi dasar acuan Pemerintah Kota Yogyakarta untuk menyelenggarakan inovasi pelayanan akta kelahiran. Inovasi ini bertujuan untuk meningkatkan kualitas pelayanan dan mengatasi persoalan terkait program sebelumnya yang kurang menampakkan hasil yang memuaskan.

\section{Inovasi Pelayanan Akta Kelahiran} Melalui E-Government di Dinas Kependudukan dan Pencatatan Sipil Kota Yogyakarta

Keoptimalan sebuah inovasi pelayanan akta kelahiran online dianalisis dengan teori atribut inovasi oleh Rogers (dalam Yogi Suwarno,2008:16-18) sebagai jawaban atas permasalahan dan kebutuhan pelayanan publik. Adapun atribut inovasi yang ada dalam inovasi pelayanan akta kelahiran melalui e-Government adalah sebagai berikut.

\section{Relative Advantage atau} Keuntungan Relatif.

Dalam inovasi akta kelahiran online, diciptakan dengan tujuan untuk memberikan pelayanan yang lebih baik. Berdasarkan level inovasi menurut Mulgan dan Albury (dalam Khairul Muluk, 2008:46), inovasi pelayanan akta kelahiran online masuk ke dalam tahap inovasi inkremental dimana inovasi ini merupakan inovasi baru yang membawa perubahan kecil terhadap proses layanan yang ada. Dengan diberlakukannya sistem online, pelayanan tersebut merupakan bentuk nilai kebaruan yang terjadi. Nilai ini membedakan dari inovasi sebelumnya dikarenakan memiliki nilai keuntungan yang relatif lebih baik. Meski memiliki nilai kebaruan dan memiliki nilai keuntungan yang relatif lebih baik, dalam pelaksanaan inovasi ini jumlah pengguna pelayanan akta kelahiran online dapat dikatakan rendah. Hal ini dipengaruhi karena beberapa alasan diantaranya pemerintah terlalu banyak menyediakan jenis pelayanan sehingga akta kelahiran online kurang diperhatikan. Selain itu, faktor budaya dan pandangan masyarakat bahwa dengan datang langsung ke dinas akan memudahkan proses pelayanan juga menghambat inovasi.

Temuan terkait keunggulan inovasi didukung oleh penelitian Nur Ayyul Hisbani dkk (2015) bahwa inovasi program harus mempunyai keuntungan dibanding inovasi sebelumnya yang telah dilakukan oleh Dinas Kependudukan dan Pencatatan Sipil Kabupaten Enrekang. Penelitian tersebut mengungkapkan inovasi pelayanan pada program $e-K T P$ 
memudahkan pemerintah dalam pendataan penduduk dengan meminimalisir adanya masyarakat yang memiliki KTP ganda.

\section{Compatibility atau kesesuaian} dengan inovasi sebelumnya.

Dalam pengembangannya terhadap kesesuaian dengan inovasi yang digantinya, pengembangan inovasi dikenal dengan tahapan pengembangan inovasi yang menjelaskan alsan inovasi selalu muncul. Proses pengembangan inovasi (Yogi Suwarno, 2008:19) pada umumnya akan melewati tahapan sebagai berikut:

a. Pengenalan kebutuhan atau masalah dimana masalah sosial menjadi sebuah prioritas dalam agenda yang memerlukan pelayanan. Inovasi yang dilakukan oleh Dinas Kependudukan dan Pencatatan Sipil Kota Yogyakarta muncul karena masalah terkait akses untuk mendapatkan pelayanan. Kesulitan yang terjadi jika dilihat dengan inovasi sebelumnya adalah ketidaksanggupan masyarakat untuk mengakses pelayanan akta kelahiran secara reguler karena keterbatasan mengakses dari segi waktu. b. Riset Dasar dan Aplikatif dimana inovasi pada umumnya selalu identik dengan teknologi. Adapun manfaat teknologi (Khairul Muluk, 2008:43) dalam pengembangan inovasi adalah untuk meningkatkan kualitas pelayanan publik, partisipasi masyarakat, dan transparansi dalam melakukan inovasi. Melalui inovasi pelayanan publik, Dinas Kependudukan dan Pencatatan Sipil Kota Yogyakarta menggunakan perkembangan teknologi internet untuk melayani kebutuhan masyarakat mengurus akta kelahiran. Adapun dalam pengembangan teknologi (Yogi Suwarno, 2008:19) terdiri dari dua aspek penting, yaitu: 1) aspek hardware (material) dalam menunjang inovasi di Dinas Kependudukan dan Pencatatan Sipil Kota Yogyakarta dengan melalui media komunikasi seperti telepon, handphone, komputer, dan peralatan lain dalam menunjang inovasi pelayanan, 2) Aspek software (perangkat lunak) yang terdiri atas pengetahuan (knowledge), keterampilan (skills), dan 
prosedur yang meliputi pegawai berkompeten di bidang teknologi.

c. Aspek Pengembangan.

Pengembangan ide-ide baru ke dalam bentuk yang dilakukan Dinas Kependudukan dan Pencatatan Sipil Kota Yogyakarta yang didorong dengan apa yang sudah menjadi visi dan misi dari pengembangan Pemerintah Kota Yogyakarta untuk persiapannya menuju Smart City.

d. Komersialisasi.

Menurut Yogi Suwarno (2008:20) Komersialisasi didalam di sektor publik, tidak dikenal istilah komersialisasi. Komersialisasi inovasi yang dimaksudkan dalam hal ini adalah distribusi dan konsumsi sebuah produk inovasi oleh masyarakat. Pemerintah Kota Yogyakarta melakukan sosialisasi untuk menyebarluaskan produk inovasi nya yaitu pelayanan pembuatan akta kelahiran online.

e. Difusi dan adopsi.

Pada tahap ini produk inovasi pelayanan akta kelahiran secara online telah hadir sebagai pemenuhan kebutuhan yang dihadapi sebagian masyarakat mengurus pelayanan akta kelahiran online. Dalam konteks difusi inovasi, maka critical mass (Yogi Suwarno, 2008:49) adalah masa di mana telah cukupnya sejumlah individu dalam sebuah sistem dalam mengadopsi sebuah produk inovasi yang ditawarkan pemerintah. Dinas Kependudukan dan Pencatatan Sipil kota Yogyakarta dimana meskipun ditahap sebelumnya masih terdapat masyarakat yang tidak mengenal produk pelayanan online, masyarakat mulai menentukan pilihannya untuk mengakses pelayanan online atau pelayanan pembuatan akta kelahiran dengan cara yang lain.

f. Konsekuensi.

Dinas Kependudukan dan Pencatatan Sipil Kota Yogyakarta telah memberikan alternatif pilhan pelayanan melalui online sehingga masyarakat dapat mengakses pelayanan. Dibuktikan dengan peningkatan jumlah kepemilikan akta kelahiran bagi masyarakat Kota Yogyakarta dari tahun 2016 ke tahun 2017 dengan peningkatan sejumlah 19.571 jiwa yang memiliki akta kelahiran. 
Melalui pengembangannya, sebuah produk inovasi tidak serta merta memecahkan masalah atau dapat menjawab kebutuhan yang muncul (Yogi Suwarno, 2008:22). Pendapat tersebut menjelaskan bahwa seandainya sebuah produk inovasi tidak berhasil, maka akan muncul kebutuhan akan inovasi yang lebih baru, atau memodifikasi inovasi tersebut untuk disesuaikan dengan permasalahan atau kebutuhannya. Proses ini disebut dengan siklus inovasi.

Adapun di Dinas Kepedudukan dan Pencatatan Sipil Kota Yogyakarta, inovasi bukanlah suatu hal yang secara menyeluruh adalah baru. Namun inovasi bagi pemerintah kota adalah suatu hal yang bisa diadopsi dari inovasi di daerah lain atau kelanjutan dari inovasi sebelumnya. Dalam indikator ini, dapat dikatakan bahwa inovasi pelayanan akta kelahiran melalui $e$ - Government yang dilakukan Dinas Kependudukan dan Pencatatan Sipil Kota Yogyakarta sesuai dengan inovasi sebelumnya. Jika sebelumnya pelayanan dilakukan secara reguler dengan berbagai pilihan layanan, maka inovasi secara online ini hadir sebagai penyempurna inovasi sebelumnya. Hal yang membedakan hanya dalam mekanisme pelayanan yang menjadi lebih sederhana dan efektif.
Dengan pemberlakuan secara online, hal yang menjadi fokus perubahannya yaitu ketika melakukan pendaftaran, mekanisme antre, dan efisiensi dokumen yang harus dikumpulkan secara paper based dapat disederhanakan menjadi bentuk digital. Dengan adanya inovasi lain yang mendukung inovasi online, maka kesesuaian inovasi secara online sesuai dengan inovasi sebelumnya. Selain sifat kompatibel atau kesesuaiannya, inovasi harus dapat memudahkan proses adaptasi dan pembelajaran terhadap inovasi secara lebih cepat. Proses pembelajaran dalam Dinas Kependudukan dan Pencatatan Sipil dapat dilihat dari kesiapan pegawai untuk menerima inovasi. Inovasi melalui online ini juga memiliki sifat relatif. Hal ini dikarenakan selain terdapat beberapa kelebihan yang didapatkan lebih baik dari inovasi sebelumnya, inovasi ini tidak sepenuhnya memiliki nilai keuntungan.

3. Complexity atau Kerumitan Dengan sifatnya yang baru.

Inovasi memiliki tingkat kerumitan yang boleh jadi lebih tinggi dibandingkan dengan inovasi sebelumnya. Senge (dalam Khairul Muluk, 2008:61) mengkombinasikan pemikiran sebagai organisasi pembelajaran untuk mengurangi sebuah 
kerumitan. Pendapat serupa tentang kompleksitas kerumitan inovasi disampaikan oleh Mulgan dan Albury (dalam Khairul Muluk, 2008:44) bahwa inovasi yang berhasil merupakan kreasi dan implementasi dari proses, produk layanan, dan metode pelayanan baru yang merupakan hasil pengembangan nyata dalam hal efisiensi, efektivitas, atau kualitas hasil.

Hasil temuan penelitian serupa dengan pendapat yang disampaikan oleh Mulgan dan Albury bahwa karena sebuah inovasi menawarkan cara yang lebih baru dan lebih baik, maka tingkat kerumitan inovasi di Dinas Kependudukan dan Pencatatan Sipil Kota Yogyakarta pada umumnya tidak menjadi masalah penting karena faktor kesiapan pegawai. Meskipun demikian, kerumitan yang terjadi adalah dalam pelaksanaan inovasi akta kelahiran online belum ada pegawai yang secara khusus untuk melayani pelayanan secara online. Namun pada umumnya pegawai pada Dinas Kependudukan dan Pencatatan Sipil Kota Yogyakarta sudah siap dan mampu beradaptasi dengan diterapkannya inovasi pelayanan online.

4. Triability atau Kemungkinan dicoba. Inovasi akta kelahiran online telah diberlakukan secara sah setelah uji publik yang telah dilakukan ketika launching. Dalam melakukan inovasi dan transformasi terdapat tahapan dalam proses inovasi e-Government, yang sesuai dengan teori (Richardus Eko Indrajit, 2002:29) bahwa tahapan kunci sukses melakukan inovasi dan transformasi adalah sebagai berikut:

a. e-Government harus merubah prinsip service to citizens menjadi service by citizens. Dalam pelaksanaannya, inovasi yang dilakukan oleh Dinas Kependudukan dan Pencatatan Sipil Kota Yogyakarta telah merubah mekanisme pelayanan yang biasanya melayani, masyarakat dapat mengakses pelayanan online secara mandiri, meskipun masih berjalan secara parsial.

b. Mengubah fenomena citizen in line menjadi citizen on line. Dengan diberlakukannya inovasi online, maka masyarakat tidak perlu mengantre di kantor dinas. Cukup melalui web dinas dan mengaksesnya, masyarakat dapat menerima pelayanan pembuatan akta kelahiran. Masyarakat yang sudah mengakses pelayanan kemudian hanya datang ke dinas hanya 
untuk mengambil akta kelahiran yang sudah jadi.

c. Mengatasi permasalahan digital divide dan menjamin terciptanya digital democracy. Dengan pemanfaatan pelayanan akta kelahiran secara online telah menciptakan sebuah lingkungan yang demokratis dimana segala akses informasi tidak hanya disampaikan satu pintu pemerintah saja namun masyarakat juga bisa memberikan masukan, saran, dan juga dapat langsung berosialisasi dengan petugas melalui media telepon maupun internet. Terkait digital devide, penelitian yang dilakukan sebelumnya oleh Dimas

Ariyoso dan Lisman Manurung (2013) bahwa langkah yang terbaik dalam mengurangi kesenjangan digital adalah menyiapkan masyarakat untuk dapat menangani, menerima, menilai, memutukan dan memilih informasi yang tersedia. Dengan kemajuan teknologi pun, masyarakat mendapat kemudahan akses untuk menggunakan dan memperoleh informasi secara merata. d. Meningkatkan efisiensi dan efektivitas pemerintah dengan meggantikan proses- proses secara paper based dengan menerapkan seara utuh konsep government online. Meskipun tidak secara menyeluruh menjadi government online, pemerintah tetap menjalankan sebagaimana yang diamanatkan dalam Undangundang. Dalam pelaksanaan inovasi pelayanan akta kelahiran online, memiliki hambatan terkait Peraturan Pemerintah yang mengatur pelaksanaan pelayanan akta kelahiran secara online sampai saat ini belum dikeluarkan.

e. Mencoba untuk menggunakan digital knowledge. Hasil dari inovasi yang dilakukan oleh Dinas Kependudukan dan Pencatatan Sipil Kota Yogyakarta yang berupa pengolahan data dan informasi yang mengalir didalam infrastruktur akta secara online dapat dimanfaatkan dan dijadikan sumber pengetahuan bagi siapa saja yang membutuhkan. Dalam pelaksanaan digital knowledge, kurang berjalan dengan baik dikarenakan dalam proses 
sosialisasinya saja terkait akta lahir online masih kurang.

Masa uji coba inovasi dilakukan selama enam bulan sebelum pelayanan akta kelahiran secara online tersebut di launching kan. Selain teruji terlebih dahulu, kemanfaatannya juga harus dapat dirasakan memiliki nilai lebih dari pelayanan lainnya. Meskipun demikian, pelaksanaan pelayanan akta kelahiran masih berjalan secara parsial karena Peraturan Pemerintah dari UU No.24 Tahun 2013 belum keluar hingga saat ini awal tahun 2018.

\section{Observability atau Kemudahan diamati}

Inovasi pelayanan akta kelahiran melalui e-Government ini harus bisa diamati dari segi bagaimana pelayanan secara online ini bekerja dan menghasilkan sesuatu yang lebih baik. Sehingga dari hasil yang baik berupa produk layanan akta kelahiran, dapat mendorong partisipasi publik dalam mendukung inovasi pelayanan. Menurut Cooper sebagaimana dikutip oleh McLaverty (dalam Yogi Suwarno, 2008:77) menjelaskan bahwa partisipasi publik merupakan sarana untuk memenuhi hak dasar sebagai warga untuk mengatahui adanya sebuah kebijakan. Pada akhirnya tujuan dari partisipasi publik adalah untuk mendidik dan memberdayakan warga. Dalam pelaksanaannya, Dinas Kependudukan dan Pencatatan Sipil Kota Yogyakarta telah melakukan berbagai upaya agar masyarakat dapat mengetahui adanya inovasi yang diciptakan pemerintah sehingga tujuan inovasi ini adalah pengguna pelayanan akta kelahiran online meningkat. Meski pemerintah sudah melakukan upaya untuk memudahkan masyarakat dalam melakukan pengamatan atau menerima informasi terkait inovasi yang diberlakukan salah satunya melalui proses sosialisasi, hal ini tidak menjamin keberhasilan program yang terjadi. Dari indikator ini dapat dikatakan belum tercapai karena pengamatan dan penilaian yang seharusnya dilakukan masyarakat untuk berpatisipasi terhadap inovasi pelayanan memiliki kekurangan yaitu dari proses sosialisasi.

Faktor pendorong dan faktor penghambat Inovasi Pelayanan Akta Kelahiran melalui e-Government di Dinas Kependudukan dan Pencatatan Sipil Kota Yogyakarta
1. Faktor Pendorong
Faktor pendorong inovasi pelayanan publik menurut Fontana 
(dalam Data Katalog dalam Terbitan KDT, 2013:30) ada faktor organisasi, faktor budaya, dan faktor manusia. Adapun yang disampaikan Fontana tersebut, sejalan dengan temuan penelitian yaitu sebagai berikut:

a. Kepemimpinan yang mendukung inovasi.

Sejalan dengan pendapat Khairul Muluk (2008:49) bahwa proses inovasi pelayanan publik membutuhkan pemimpin yang mampu melakukan perubahan, mampu menyadarkan banyak pihak, dan mampu menggerakkan serta memberikan teladan yang mendukung proses inovasi. Dari temuan penelitian dengan kesesuaian teori di atas, dorongan pemimpin mulai dari Pemerintah Pusat, Walikota Yogyakarta, Kepala Dinas memiliki visi dan misi yang kemudian diwujudkan bersama hingga Sekretaris Dinas dan Kepala Seksi untuk bersama mewujudkan terobosan untuk memberikan pelayanan yang terbaik untuk masyarakat.

b. Dukungan pegawai untuk melakukan pelayanan sesuai janji pelayanan.

Dalam aktivitas pelayanan, pegawai di Dinas
Kependudukan dan Pencatatan Sipil Kota Yogyakarta memiliki janji layanan. Sesuai dengan pendapat Fontana (dalam Data Katalog dalam Terbitan KDT, 2013:30) faktor organisasi adalah meliputi orang atau kelompok dalam organisasi dalam organisasi (pegawai) yang mendukung inovasi. Inovasi pelayanan akta kelahiran melalui e-Government di Dinas Kependudukan dan Pencatatan Sipil Kota Yogyakarta dipengaruhi semangat pegawai dalam mendorong inovasi pelayanan. Hal ini dibuktikan dengan adanya penerapan janji tersebut melalui maklumat atau janji layanan. Peran pegawai menjadi faktor yang penting sebagai pendorong dilaksanakannya sebuah inovasi. Pegawai di dinas juga berorientasi pada standar pelayanan publik dimana hal tersebut akan menjadi acuan untuk menyelenggarakan pelayanan.

c. Dorongan oleh masyarakat untuk mewujudkan pelayanan yang baik.

\section{Masyarakat}

berpengaruh

dalam 
memberikan dorongan terhadap inovasi akta kelahiran online. Hal ini sesuai dengan yang disampaikan oleh Khairul Muluk (2008:53) bahwa masyarakat dan budaya menjadi begitu penting karena inovasi sebenarnya perlu dibangun di atas basis sosial yang luas dan tidak dibatasi oleh periode waktu yang terbatas. Dari temuan penelitian, terbukti bahwa ketika Dinas Kependudukan dan Pencatatan Sipil Kota Yogyakarta melakukan sosialisasi di setiap kelurahan, terdapat saran dan masukan dari masyarakat terkait kebutuhan pelayanan publik yang diinginkan masyarakat. Kebutuhan terkait pelayanan adalah pemanfaatan teknologi internet yang disampaikan warga akan memudahkan masyarakat dalam mengakses pelayanan. Untuk itu, saran dan masukan tersebut diterima dan dikembangkan oleh Dinas Kependudukan dan Pencatatan Sipil.

\section{Faktor Penghambat}

Faktor penghambat inovasi di Dinas Kependudukan dan Pencatatan
Sipil Kota Yogyakarta diidentifikasi memiliki perbedaan dengan pendapat ahli Albury (dalam Yogi Suwarno,2008:5455). Adapun faktor penghambat inovasi pelayanan akta kelahiran online adalah sebagai berikut:

a. Faktor budaya masyarakat. Temuan penelitian menunjukkan bahwa budaya sangat berpengaruh terhadap proses inovasi. Budaya masyarakat di Kota Yogyakarta dalam menerima pelayanan publik menjadi penghambat dikarenakan support yang rendah menggunakan pelayanan online. Selain itu cara pandang masyarakat memilih untuk bersosialisasi dengan petugas juga menghambat inovasi pelayanan yang dilakukan secara online.

b. Pilihan masyarakat untuk menggunakan inovasi lain. Menurut pendapat Yogi Suwarno (2008:89) secara konsep, keputusan individu dalam inovasi pelayanan publik berbeda dengan keputusan sebuah organisasi dalam mengadopsi inovasi. Inovasi pelayanan yang dilakukan Dinas Kependudukan dan Pencatatan Sipil Kota Yogyakarta tidak hanya dilakukan melalui 
pelayanan secara online saja, namun terdiri dari berbagai bentuk pelayanan pembuatan akta kelahiran. Selain pembuatan akta kelahiran online terdapat pilihan pelayanan yang lain seperti pelayanan jemput bola dan pelayanan akta 3 in 1 . Sebagai pengguna, tentu saja masyarakat memiliki pilihan untuk memilih jenis dan model pelayanan seperti apa yang dipilih.

c. Kurangnya sosialisasi inovasi pelayanan akta kelahiran online kepada masyarakat. Menurut Yogi Suwarno konsumen atau masyarakat mulai dipengaruhi sikap dan perilakunya agar positif atau sejalan dengan misi dari produk inovasi. Dari pendapat tersebut, temuan penelitian mengetahui bahwa kurangnya sosialisasi menjadi faktor penghambat inovasi pelayanan akta kelahiran online. Sehingga dalam kenyataannya masih terdapat masyarakat yang tidak mengetahui adanya kebijakan akta kelahiran online. Beberapa pengguna layanan akta kelahiran online berpendapat bahwa sosialisasi terkait adanya inovasi tersebut harus semakin digencarkan karena masih banyak masyarakat Kota Yogyakarta yang belum mengetahui adanya inovasi pelayanan publik tersebut.

d. Belum dikeluarkannya petunjuk pelaksanaan pelayanan akta kelahiran online dari pemerintah pusat. Inovasi pelayanan akta kelahiran secara online berjalan sebagaimana mestinya sesuai dengan Undangundang Nomor 24 Tahun 2013 yang mengatur pelaksanaan pelayanan akta online. Namun hingga saat ini awal tahun 2018, Peraturan Pemerintah sebagai petunjuk pelaksanaan UU Nomor 24 Tahun 2013 belum dikeluarkan oleh Pemerintah Pusat. Oleh karena itu, pelaksanaan pelayanan akta kelahiran secara online masih dilaksanakan secara parsial (belum sepenuhnya online).

\section{SIMPULAN}

Hasil penelitian menunjukkan bahwa Inovasi Pelayanan Akta Kelahiran melalui E-Government di Dinas Kependudukan dan Pencatatan Sipil Kota 
Yogyakarta belum optimal. Hal tersebut dapat dilihat yaitu: 1) jumlah pengguna akta kelahiran online rendah, 2) inovasi pelayanan yang ditawarkan pemerintah terlalu banyak, 3) belum ada petugas khusus yang melayani akta kelahiran online, 4) pelaksanaan pelayanan akta kelahiran online yang masih parsial, 5) ketidaktahuan masyarakat terkait inovasi pelayanan akta kelahiran online. Inovasi ini didorong dengan adanya 1) kepemimpinan yang mendukung inovasi, 2) dukungan pegawai untuk menyelenggarakan pelayanan sesuai janji layanan, 3) dorongan masyarakat. Adapun hambatan dalam inovasi ini yaitu 1) kecenderungan masyarakat untuk mengakses pelayanan secara reguler, 2) pilihan masyarakat terhadap bentuk pelayanan lain yang disediakan, 3) kurangnya sosialisasi, 4) belum dikeluarkannya Peraturan Pemerintah sebagai petunjuk pelaksanaan pelayanan akta kelahiran online.

\section{DAFTAR PUSTAKA}

Ahmadi, Rulam. 2014. Metodologi Penelitian Kualitatif. Yogyakarta:Ar- Ruzz Media

Indrajit, Richardus Eko. 2002. Electronic Government Strategi Pembangunan dan Pengembangan Sistem Pelayanan Publik Berbasis Teknologi Digital. Yogyakarta: Andi Offset
Indrajit, Richardus Eko. 2013. Jurnal $e$ artikel Sistem dan Teknologi Informasi. Seri 999 e-artikel Sistem dan Teknologi Informasi, diunduh melalui www.academia.edu

Moleong, Lexy. 2006. Metodologi Penelitian Kualitatif. Bandung: Remaja Rosdakarya

Putera, Prakoso Bhairawa. 2015. IPTEK dan Inovasi Kunci Meretas Jalan Menuju Kemandirian Bangsa. Yogyakarta: Graha Ilmu

Putera, Prakoso Bhairawa. 2015. Policy Review Teori dan Aplikasi pada Kebijakan IPTEK dan Inovasi.Yogyakarta: Graha Ilmu

Ratminto dan Winarsih, Atik Septi. 2013. Manajemen Pelayanan Pengembangan Model Konseptual, Penerapan Citizen's Charter dan Penerapan Standar Pelayanan Minimal. Yogyakarta: Pustaka Pelajar.

Santosa, Pandji. 2012. Administrasi Publik Teori dan Aplikasi Good Governance. Bandung: PT Refika Aditama

Sugiyono. 2011. Metode Penelitian Kombinasi (Mix Method). Bandung: Alfabeta

Suwarno, Yogi. 2008. Inovasi di Sektor Publik. Jakarta: STIA-LAN Press

Tuti, Titik Triwulan. 2008. Pengantar Hukum Perdata di Indonesia.Jakarta: Perpustakaan 